\title{
A double-hurdle model estimation of cocoa farmers' willingness to pay for crop insurance in Ghana
}

\author{
Elvis Dartey Okoffo ${ }^{1}$, Elisha Kwaku Denkyirah², Derick Taylor Adu ${ }^{2}$ and Benedicta Yayra Fosu-Mensah ${ }^{{ }^{*}}$ (i)
}

\author{
*Correspondence: \\ yayramensah@staff.ug.edu.gh \\ ${ }^{1}$ Institute for Environment \\ and Sanitation Studies (IESS), \\ University of Ghana, P. O. Box 209, \\ Legon, Accra, Ghana \\ Full list of author \\ information is available at \\ the end of the article
}

\begin{abstract}
Agriculture is an important sector in Ghana's economy, however, with high risk due to natural factors like climate change, pests and diseases and bush fires among others. Farmers in the Brong-Ahafo region of Ghana which is known as one of the major cocoa producing regions, face these risks which sometimes results in crop failure. The need for farmers to therefore insure their farms against crop loss is crucial. Insurance has been a measure to guard against risk. The aim of this study was to assess cocoa farmers' willingness to access crop insurance, the factors affecting willingness to pay (WTP) for crop insurance scheme and insurance companies' willingness to provide crop insurance to cocoa farmers. Multi-stage sampling technique was used to sample 240 farmers from four communities in the Dormaa West District in Brong-Ahafo Region. The double-hurdle model shows that age, marital status and education significantly and positively influenced cocoa farmer's willingness to insure their farms whiles household size and cropped area negatively influenced farmers' willingness to insure their farms. Similarly, age, household size and cropped area significantly and positively influenced the premium cocoa farmers were willing to pay whiles marital status and cocoa income negatively influenced the premium farmers were willing to pay. The contingent valuation method shows that the maximum, minimum and average amounts cocoa farmers are willing to pay for crop insurance per production cost per acre was GHC128.40, GH 32.10 and GH 499.32 respectively. Insurance companies do not have crop insurance policy but willing to provide crop insurance policy to cocoa farmers on a condition that farmers adopt modern cultivation practices to reduce the level of risk. The study recommends that cocoa farmers should be well educated on crop insurance and should be involved in planning the crop insurance scheme in order to conclude on the premium to be paid by them.
\end{abstract}

Keywords: Agriculture, Crop insurance, Cocoa, Risk, Willingness to pay, Premium

\section{Background}

Agriculture has been the key player in Ghana's economic growth and development since independence (Mahrizal et al. 2014). It employs about $70 \%$ of the labour force in Ghana, accounts for about $30 \%$ of Ghana's GDP and contributes about $60 \%$ of foreign exchange earnings through export (Ayisu 2008; ISSER 2010). Cocoa, coffee, oil palm and rubber are the main cash crops and agricultural export commodities in Ghana. Among these 
crops, cocoa (Theobroma cacao) is the major agricultural export commodity in Ghana (Anim-Kwapong and Frimpong 2004). It is successfully grown in six out of the ten regions of Ghana, namely, Ashanti, Brong-Ahafo, Central, Eastern, Western and Volta (Anim-Kwapong and Frimpong 2004). Ghana is the second largest producer of cocoa in the world after Cote D'Ivoire and is renowned for its premium quality cocoa bean (Ntiamoah and Afrane 2008; Gockowski et al. 2011). The crop contributes substantially to foreign revenue earnings, employment and domestic incomes (Ayenor et al. 2007; Anang 2011). A report by ISSER (2014) revealed that in 2013, approximately $16.48 \%$ (US\$ 2267.3 million) of total agriculture export receipts were foreign revenue earnings from cocoa. Appiah (2004), Anim-Kwapong and Frimpong (2004) and Danso-Abbeam et al. (2014) assert that in Ghana, over eight hundred thousand $(800,000)$ smallholder farm families are employed by the cocoa sector which contributes about $70-100 \%$ of their annual household income. In addition, Asamoah and Baah (2003) and Anim-Kwapong and Frimpong (2004) emphasize that other stakeholders like agrochemical companies, input distributors and licensed cocoa buying companies also depend largely on cocoa for markets of their products, employment and income.

In spite of the significant contribution of cocoa production to Ghana's economy, it is faced with many challenges such as climate change, bush fire, pests and diseases outbreak, among others resulting in crop failure and/or destruction of crops. According to Laux et al. (2010) and IPCC (2014), the spatial and temporal variability of rainfall which is reflected by recurrent dry spells and floods is the most important factor affecting crop productivity, and hence reducing food security. In addition, Johny et al. (2003) and Bailey et al. (2005) have reported that the yield of cocoa is limited by pests and diseases in many producing countries. Lass (2004), Lanaud et al. (2009) and ICCO (2015) reported that $30-40 \%$ of cocoa produced globally is lost to insect pests and diseases. These challenges pose high risk of crop loss as most farmers in Ghana are smallholders with less input and total dependence on rainfall as source of moisture for crop growth. These factors which are sometimes beyond the control of farmers make farming a risky business, hence, farmers have to manage these risks as part of the general management of the farming business. Some farmers over the years have adopted some measures such as crop diversification, increasing pesticide and fertilizer applications and planting of drought resistant crops to reduce the risk of total crop failure. However, risk continues to be a major factor in agriculture, hence, the need for farmers to guard against risk through farm insurance scheme is crucial.

According to Freshwater and Jette-Nantel (2008), there are two predominant risks that affect the income of farmers and agribusinesses. These risks are price risk and production risk. Price risk comprise of the variations in market prices for agricultural commodities and production inputs whiles production risk is the variations in the quantity and quality of agricultural commodities produced. Although there are several sources of production risk, weather is seen as the most pervasive source of production risk and its impact is felt particularly in countries that rely on rain-fed agriculture (Swiss 2007). Weather variations can severely affect the quality and quantity of crop yield and this is mostly felt in developing countries where majority of agricultural activities remain highly susceptible to extreme and uncontrollable weather events such as insufficient rainfall and extreme 
temperatures. Poor and vulnerable farming households (with majority being subsistence farmers) are mostly affected by risk due to the weather (Aidoo et al. 2014).

A risk management tool in farming could be insurance. Quagrainie (2006) stated that insurance is a tool to reduce the financial risk of adverse events such as loss of life, medical expenses, auto accidents, casualty losses and weather damage. Similarly, Adams (1995) defines insurance as a contract between two parties, where one party called insurer takes a premium from the other party (insuree) in order to pay a fixed amount of money to the insuree when there is occurrence of an unforeseen event. Insurance provides the opportunity for people to replace risk with known cost. People purchase insurance coverage with the promise of receiving an amount from the insurance organization when the policyholder experiences insurance covered loss (Nimo et al. 2011). According to Aidoo et al. (2014), almost all the insurance companies in Ghana provide various insurance schemes (e.g. auto insurance, life and health insurance, fire insurance and burglary) other than crop insurance scheme.

The Dormaa West District of the Brong-Ahafo region of Ghana is known to be one of the major cocoa-producing districts in Ghana. The district is generally an agrarian economy which contributes immensely to the food basket of the country. However, cocoa farmers in this district have over the years lost cocoa crops (particularly at the seedling stage) and yields due to spatial and temporal variability of rainfall (erratic rainfall, drought spills), insect pests and disease outbreak, bush fires, low/poor soil fertility, unavailability of farm inputs (fertilizers, pesticides, high-yielding and pest and disease resistant cocoa seedlings/varieties), high and erratic prices of farm input, ageing cocoa farmers, aging cocoa plantations, technological backwardness, illegal chain saw activities, among others. When such situations occur, farmers lose income, which affect other household members such as children dropping out of school as a result of not being able to pay their school fees and poor health care due to inability to afford medical care. The loss of income may also affect farmers' ability to purchase farm input for the next crop season, hence, worsening the already poor condition of farmers. To reduce the risk of total loss of income/or crops due to these factors, the insurance of cocoa farms by farmers is crucial. Although, many small-scale cocoa farmers in the Dormaa West District in the Brong-Ahafo Region of Ghana rely on cocoa as a source of revenue (livelihood), there is little information on cocoa farmers' willingness to insure their crop, premium willing to pay and the willingness of insurance companies to provide crop insurance scheme to farmers. This research therefore seeks to investigate (1) cocoa farmers' willingness to insure their crop and the premium they are willing to pay, (2) evaluate the factors that influence cocoa farmers' willingness to insure their crop and the premium to pay and (3) assess the willingness of insurance companies to provide crop insurance to cocoa farmers.

\section{Literature review}

\section{Analytical technique}

Review of literature on willingness to pay for agricultural insurance indicates that there are three ways of estimating farmer's willingness to pay (WTP) for insurance. They are; contingent valuation method, the revealed preference theory or approach and a combination of the use of theory along with microeconomic household variables and market 
variables to estimate indirectly the appropriate market premium. Among the stated preference methods, the contingent valuation method have been highly recommended in instances where there is no or little market information and has been widely used by many researchers (Vandeveer and Loehman 1994; Sarris et al. 2006; Liu and Zhang 2011; Nakanyike 2014; Taneja et al. 2014). This is because it helps to simulate the concept of choice in a market situation as respondents have the opportunity to accept or reject the product. As a result of the importance of the contingent valuation method, it has been highly utilized in various agriculture related studies where it was used to elicit farmers' willingness to pay for a service, product or technology. For example, Ulimwengu and Sanyal (2011) adopted the method in analyzing farmers' willingness to pay for agricultural services and the method was further used by Kwadzo et al. (2013) and DansoAbbeam et al. (2014). According to Taneja et al. (2014), the contingent valuation method makes use of surveys that are particularly intended for measuring preferences and willingness to pay. Based on its importance, the contingent valuation was used in this study.

Various studies have used either the double-hurdle model or the Heckman's sample selection model in determining the willingness to pay for insurance (Cragg 1971; Norris and Batie 1987; Gabre-Madhin et al. 2003; Sindi 2008; Wodjao 2008; Yu and Abler 2010, Musah 2013). In this study, the double-hurdle model was adopted based on its advantage over the Heckman's sample selection model. The Heckman sample selection model assumes that no zero response will be present in the second hurdle of the analysis once the first hurdle is passed whiles the double-hurdle on the other hand recognizes the possibility of zero observations in the second stage (Wodjao 2008). The possibility of zero response is as a result of the fact that the cocoa farmer may refuse to answer due to a lack of knowledge or how complex the questions are perceived to be. In addition, some cocoa farmers may only have partial information concerning their willingness to pay ( $\mathrm{Yu}$ and Abler 2010). For such a case, it is possible respondents (farmers) cannot give a number representing their WTP but may recognize the fact that they have a positive WTP. Cragg (1971) suggested a double-hurdle model in which adoption behavior consists of two decisions: an adoption decision, which is a binary choice, modelled using a Logit; and a WTP amount decision, which is a truncated regression model. The Double hurdle, is used in a situation where an event may occur or not and when it does, it takes on continuous positive values (Gabre-Madhin et al. 2003). It is assumed that the cocoa farmer is faced with hurdles in decision making process. Hence, the decision to pay is made first followed by the decision on how much to pay for the insurance. The two equations are assumed to be independent.

\section{Methods}

\section{The study area}

The study was carried out in the Dormaa West District located at the western part of the Brong-Ahafo Region of Ghana. It shares boundaries in the north with the Dormaa Central Municipality, in the east with Asunafo North Municipality, in the west with La Cote D'Ivoire and in the south west with Bia East District. It has a population of 47, 678, comprising of 24, 681 (51.8 \%) males and 22, 997 females (48.2 \%) (Ghana Statistical Services 2014). The highest mean temperature of the District is about $30{ }^{\circ} \mathrm{C}$ which occurs between March and April and the lowest about $26.1{ }^{\circ} \mathrm{C}$ in August. The District lies in the 
sub-humid zone (with annual total rainfall of $800-1200 \mathrm{~mm}$ ) and has a bimodal rainfall regime. The major economic activities in the District include the cultivation of food and cash crops (including cocoa), poultry and livestock farming, oil palm extraction, cassava processing and sand winning. Soils in the District belong to the Bekwai-Nzema compound Associations. The soil types within the study area support cultivation of both cash and domestic food crops, which include cocoa, coffee, oil palm, citrus, cola-nuts, plantain, cassava and maize, among others. The area is well drained with rivers, mostly perennial due to the bimodal rainfall regime in the area. Notable among them are the Bia, Nkasapim and Pamu rivers. These rivers are mostly used as a source of water for the cultivation of vegetables such as tomatoes, pepper and okra during the dry season. There are however, traditional restrictions on the use of the rivers for fishing (Ghana Statistical Service 2014).

\section{Sampling technique and sample size}

A total of 240 cocoa farmers were selected for the study using the multi-stage sampling technique. The Brong-Ahafo Region of Ghana was purposively selected due to the predominance of cocoa production in the region. The Dormaa West District, known to be one of the major cocoa growing districts in the Brong-Ahafo region was randomly selected. Four cocoa growing communities in the district namely; Nkrankwanta, Diabaa, Krakrom and Kwakuanya were randomly sampled and subsequently sixty (60) cocoa farmers were randomly selected from each of the four cocoa growing communities. The snowball sampling technique was used to select five insurance companies from the Sunyani Metropolis the capital of the region since the total number of insurance companies was not known.

\section{Instrumentation for data collection}

A pre-tested semi-structured questionnaire was developed as an instrument for the study. The structure of questions in the data collection instrument was a combination of close-ended, open-ended and partially close-ended questions. The survey was conducted from December, 2014 to March, 2015.

\section{Theoretical framework}

The theory underpinning this study is utility maximization. Thus, for a farmer to make decision on whether or not to adopt a particular technology or innovation, he does not only consider how to maximize profit from that innovation but on how to attain the highest level of utility otherwise referred to as utility maximization (Sadoulet et al. 1996; McConnell et al. 2009). It was observed that farmers have a level of utility they want to meet and therefore make choices based on their level of utility. For instance, given a number of utility levels ' $K$ ', a farmer will choose a level that conforms to the highest level of utility given his budget. Such discrete choice scenarios are modeled using the random utility theory (Lubungu et al. 2012).

The utility of a farmer is given as $U_{i j}$, from choosing alternative $j$. A cocoa farmer will choose whether or not to adopt crop insurance depending on the relative utility levels associated with the two choices. Therefore, the probability that alternative $j$ will be chosen is given by 


$$
P(y i=j)=p(U i j \geq U t k \mid X, \phi k=j)=P\left(\varepsilon t k-\varepsilon i j \leq X_{i j}^{\prime} \beta j-X_{i j}^{\prime} \beta k \mid X, \phi k \neq j\right)
$$

where $y_{i}$ is the observed outcome for the $i$ th observation. $i=1, \ldots, N$ indexes the cocoa farmer, $j=1, \ldots, j$ and $k=1, \ldots, k$ are the alternatives being considered, $X$ is a vector of farmer, farm and institutional characteristics, $\beta$ is a vector of parameters to be estimated and $\varepsilon$ is the stochastic random error. Even though the difference in the utilities $\left(\mathrm{V}_{\mathrm{i}}\right)$ of adoption and non-adoption are unobserved,

$$
\mathrm{V}_{\mathrm{i}}=\mathrm{U}_{\mathrm{ij}}-\mathrm{U}_{\mathrm{ik}}
$$

The decision of a farmer is taken as a binary outcome such that

$$
J i \in j=\{1 \text { if } V>0, \quad 0 \text { otherwise }\}
$$

It is assumed from this that the cocoa farmer selects the alternative choices of adoption and non-adoption of crop insurance based on the highest level of utility. This implies that if adoption will enhance his/her highest level of utility, then the farmer will go for that option.

\section{Empirical model}

The first equation in the Double-Hurdle relates to the willingness to adopt crop insurance scheme. A probit regression on the willingness to adopt or not is modeled as:

$$
\begin{aligned}
& W T I=1 \quad \text { if } W T I>0 \quad \text { and } \quad W T I=0 \quad \text { if } \quad W T I \leq 0 \\
& W T I=z i^{\alpha} \alpha+\varepsilon i
\end{aligned}
$$

WTI is a dichotomous variable which assumes a value of 1 and 0 otherwise, $\mathrm{z}$ is a vector of farmer, farm and institutional characteristics, $\alpha$ is a vector of parameters and $\varepsilon_{i}$ is the error term.

The empirical model for cocoa farmer's willingness to adopt crop insurance is specified for this study as;

$$
\begin{aligned}
\text { WTI }= & \beta_{0}+\beta_{1} \text { Age }+\beta_{2} \text { Gender }+\beta_{3} \text { Mstatus }+\beta_{4} \text { Educ }+\beta_{5} \text { Hsesize } \\
& +\beta_{6} \text { Croparea }+\beta_{7} \text { Cocoainc }+\beta_{8} \text { Otherinc }+\varepsilon_{i}
\end{aligned}
$$

WTI is the probability that an $i$ th cocoa farmer is willing to adopt crop insurance. $\beta_{i}$ is the coefficients of the explanatory variables. $\varepsilon_{i}$ is the error term.

The second hurdle which estimates the amount (premium) cocoa farmers are willing to pay is estimated using a regression truncated at zero. It is expressed as;

$$
\begin{aligned}
& \text { WTPamt }_{i}=\text { WTPamt }_{i}^{*} \text { if WTPamt } \text { WT }_{i} 0 \text { and WTPamt }{ }_{i}^{*}=0 \text { if otherwise } \\
& W_{\text {TPamt }}^{*}=x_{\mathbf{i}}^{\prime} \beta+u_{\mathbf{i}}
\end{aligned}
$$

Where WTPamt* is the observed response on how much cocoa farmers are willing to pay for crop insurance. $X$ is the vector of farmer, farm and institutional characteristics, $\beta$ is a vector of parameters and $u_{\mathrm{i}}$ is the error term which is randomly distributed.

The empirical model of the truncated regression model (tobit model) is specified for this study as; 


$$
\begin{aligned}
\text { WTPamt }_{i}= & \beta_{0}+\beta_{1} \text { Age }+\beta_{2} \text { Gender }+\beta_{3} \text { Mstatus }+\beta_{4} \text { Educ }+\beta_{5} \text { Hsesize } \\
& +\beta_{6} \text { Croparea }+\beta_{7} \text { Cocoainc }+\beta_{8} \text { Otherinc }+\varepsilon_{i}
\end{aligned}
$$

where WTP amt $\mathrm{i}_{\mathrm{i}}$ is the amount an $i$ th cocoa farmer is willing to pay, $\beta_{i}$ are parameters to be estimated and $\varepsilon_{\mathrm{i}}$ is the error term.

\section{Definition of variables}

Age of cocoa farmer (Age)

Age of cocoa farmers was measured in years in this study. It is hypothesized that age can negatively influence a farmer's willingness to insure his farm. Older farmers are less likely to adopt crop insurance than younger farmers. This is due to the fact that older farmers tend to gather experience from farming and stick to primitive ways of production and do not easily adopt newly introduced technology (Baidu-Forson 1999; Langyintuo and Mulugetta 2005).

\section{Gender of cocoa farmer (Gender)}

Gender was measured as a dummy variable with male farmers $=1$ and female farmers $=0$. Gender is hypothesized to be positive. This is due to the fact that male farmers are well endowed with resource such as land than their female counterparts, therefore, the higher the probability of male farmers adopting crop insurance and the higher the amount (premium) paid.

\section{Marital status (Mstatus)}

Marital status was measured as dummy with married farmers $=1$ and single farmers $=0$. Marital status is hypothesized to be positive due to the fact that married farmers will consider the survival of their family should any uncertainty strikes (Danso-Abbeam et al. 2014). Therefore, the more likely they would be willing to accept crop insurance policy and pay higher amount as premium.

\section{Education of cocoa farmer (Educ)}

It is assumed that a farmer who has gained formal education can critically analyze and make own decisions between technologies (Enete and Igbokwe 2009; Caleb and Ramatu 2013). Therefore, a farmer who has gained formal education is more likely to adopt crop insurance and pay higher amounts as premium.

\section{Household size (Hsesize)}

It is hypothesized that household size can positively or negatively influence a farmer to adopt crop insurance scheme. This is due to the fact that a farmer who has large household size may not want to spend his/her income in any other activities but use it to cater for his/her household. Also, a farmer would adopt crop insurance scheme based on the fact that he would not like to take the risk of losing his farm at the expense of his household in case of disaster. 
Table 1 Demographic characteristics of cocoa farmers

\begin{tabular}{llc}
\hline Variable & Description & Percentage (\%) \\
\hline Gender & Male & 87.5 \\
Age & Female & 12.5 \\
& $20-29$ & 2.1 \\
& $30-39$ & 8.3 \\
& $40-49$ & 32.5 \\
Marital status & $50-59$ & 31.3 \\
& Above 60 & 25.8 \\
Educational level & Single & 28.3 \\
& Married & 71.7 \\
Years of farming experience in cocoa & No education & 18.8 \\
& Primary/JHS & 34.6 \\
& Middle/SHS & 43.3 \\
& Tertiary & 3.3 \\
& $5-10$ & 5.8 \\
\hline
\end{tabular}

\section{Size of cropped area (Croparea)}

The size of cropped area was measured in acres. It is hypothesized that the larger the cropped area, the more likely the farmer would adopt crop insurance. This is because, it is difficult to manage a large portion of farm land than a smaller portion and therefore, the more likely the farmer is to face risk like low yield and pest infestation or the impact a farmer would experience in times of perils is greater with large farm size. On the other hand, the premium a farmer will pay would increase as the size of cropped area increases.

\section{Cocoa income (Cocoainc)}

The cocoa income was measured as the sale of a kilogram of dried cocoa bean in the year under review. It is hypothesized to be positive. The reason being that as the income of the cocoa farmer increase, the higher the probability of purchasing crop insurance scheme and the higher the premium they will be willing to pay.

\section{Income from other sources (Otherinc)}

It is assumed that income from other sources can increase the likelihood of a cocoa farmer purchasing an insurance scheme. This is based on the fact that the income from other sources adds up to the income from the sale of cocoa, making the income stream of the farmer greater, hence, the higher the probability to afford an insurance scheme and the higher the amount paid as premium.

\section{Results and discussion}

\section{Demographic characteristics of farmers}

The demographic characteristics of farmers are presented in Table 1. A total of $87.5 \%$ of the respondents were males while $12.5 \%$ were females. Majority (63.8 \%) of the 
Table 2 Production risk faced by cocoa farmers in the study area

\begin{tabular}{ll}
\hline Risks & Percentage (\%) \\
\hline Insects pest and diseases & 95.8 \\
High and erratic prices of farm input & 81.7 \\
Illegal chain saw activities & 30 \\
Erratic rainfall and long drought spills & 70 \\
Bush fire & 8 \\
Unavailability of farm inputs & 25 \\
Ageing cocoa farmers & 20
\end{tabular}

Multiple response analysis

respondents were aged between 40 and 59 years while $25.8 \%$ were above 60 years. Only $10.4 \%$ of the farmers were between the ages of 20-39 years. The mean age of the cocoa farmers was 52 years and the maximum age was about 83 years. Majority of the cocoa farmers $(71.7 \%)$ were married whiles $28.3 \%$ were single. About $81.2 \%$ of the respondents had formal education, mostly middle/senior high school (43.3\%), primary/junior high school education (34.6\%) and tertiary education (3.3\%), with $18.8 \%$ of the farmers having no formal education. As shown in Table 1 about $94.2 \%$ of the farmers had 11 or more years of farming experience in cocoa production. The average number of years' farmers have been in cocoa farming in the study area was 21.8 .

\section{Major cocoa production constraints/risks}

Table 2 presents the risks identified by cocoa farmers in the study area. Insect pests and diseases were identified as the major risk by the farmers, followed by high and erratic prices of farm inputs. Erratic rainfall and long drought spills was identified as a risk which they attributed to climate change. Similarly, farmers complained of illegal chainsaw activities which they said sometimes destroy their crops. A few of the farmers also indicated the incidence of bush fires which sometimes destroy their crops. In a surprising turn, ageing of cocoa farmers was mentioned by some farmers as a risk to cocoa production in the study area.

According to Dormon et al. (2004), the incidence of insect pests and diseases is a major challenge in cocoa production in Ghana and has resulted in low yields due to inadequate management. Duguma et al. (1998), Lass (2004) and Dormon et al. (2007) estimate losses by insect pests and diseases to be $30 \%$ of global yields of cocoa annually, whereas site-specific losses ranging from 10 to $80 \%$ annually have been reported. In Ghana, the mirids (capsids) and the black pod disease are the most destructive of the number of insect pests and diseases which attack the developing cocoa tree and the development or ripening of cocoa pod. Farmers in the study area identified mirids as the major insect pest. Other insect pests of cocoa mentioned included termites, mealy bugs, ants, mites, shield bugs, stem borers, and pod borers. This confirms the fact that marids remain the insect pest of economic importance in Ghana (Antwi-Agyakwa 2013). The major cocoa disease mentioned by farmers was the black pod followed by the cocoa swollen shoot virus. Mistletoe a parasitic plant and rodents were also mentioned by some farmers to cause decline in cocoa production in the study area. According to the farmers, capsid and black pod attacks were the major causes of pre-harvest losses in their cocoa farms 
(65 and $45 \%$ of the respondents respectively). On the other hand, $17 \%$ of the respondents reported that rodents were among the pests of cocoa causing pre-harvest losses and this could be attributed to poor maintenance of farms. However, some farmers could not differentiate between damages caused by these insect pest and diseases and as such misinterpreted the damage of one insect pest or disease for the other.

Climate change and variability is another major risk farmers are facing in the study area. According to Laux et al. (2010) and IPCC (2014), the spatial and temporal variability of rainfall which is reflected by recurrent dry spells and floods is the most important factor affecting crop productivity. Cocoa is highly susceptible to drought and the pattern of cropping of cocoa is related to rainfall distribution. Significant correlations between cocoa yield and rainfall over varying intervals prior to harvest have been reported (Anim-Kwapong and Frimpong 2004). Farmers complained of erratic rainfall and long drought spills resulting in serious shocks in seedlings development and poor yields (Longe and Oyekale 2013). Anim-Kwapong and Frimpong (2004) reported that, dry weather results in soil water deficit resulting in high seedling mortality at the establishment phase. They also indicated that during the pod filling stage, the occurrence of short dry spills affects bean size and hence the quality of cocoa beans produced. This affects the farmer's income as the quality of cocoa bean is considered when pricing the beans. It was also reported that heavy rainfall between August and October prevents cocoa trees from flowering. Climate change is also expected to alter stages and rates of development of cocoa pests and pathogens, modify host resistance and result in changes in the physiology of host-pathogen/pests interaction (Anim-Kwapong and Frimpong 2004; Kimengsi and Tosam 2013). The most likely consequences are shifts in the geographical distribution of host and pathogen/pests, altered crop yields and crop losses which, will impact socio-economic variables such as farm income, livelihood and farm-level decision making (Anim-Kwapong and Frimpong 2004; Kimengsi and Tosam 2013). According to Anim-Kwapong and Frimpong (2004), the black pod disease of cocoa is closely related to climate and is more prevalent in damp areas. Black pod disease accounts for the bulk of annual production losses of cocoa in Ghana and is most destructive in years when the short dry period between July and August is very wet whiles mirids (capsids) which are sucking insects are usually most active and destructive from September to March particularly when moisture deficit is severe. Excessive shade and bushy farms nearby cocoa farms were identified by $75 \%$ of the farmers to be the major causes of mirids attack on their cocoa farms. Additionally, $70 \%$ of the farmers reported excessive rainfall, excessive shading and stagnant water on their cocoa farms as the cause of black pod disease.

The high incidence of cocoa insect pests and diseases, low soil fertility and bad weather/poor climate (erratic rainfall and long drought spills, strong winds, etc.) results in increased use of pesticides and fertilizers, and planting of improved cocoa varieties by farmers in the study area. However, the farmers indicated that the government of Ghana interventions-supply of high-yielding and disease resistant cocoa seedlings, distribution of fertilizers and mass spraying (spraying of cocoa farms with pesticides) were totally inadequate to revive the sector. For instance, the farmers indicated that cocoa farms in the district are to be sprayed four times a year, between July and November under the Government of Ghana mass cocoa spraying Programme with Ghana Cocoa 
Board (COCOBOD) approved pesticides. However, in the year of the study, only $51.7 \%$ had their farms sprayed once while only $6.9 \%$ of the farmers had their farms sprayed four times. According to Aneani et al. (2012) and Danso-Abbeam et al. (2014), spraying frequency of the 'mass spraying exercise' is not adequate and cocoa farmers are expected to do additional spraying. This situation made farmers in the study area to purchase pesticides from the open market which they claim are very expensive, hence, impacting on cocoa production. This finding confirmed the study by Dormon et al. (2004) which reported that most cocoa farmers in Ghana are not able to control insect pests and diseases on their farms due to high cost of pesticides, spraying equipment and labour (sprayers) resulting in poor yield and in some cases total destruction of cocoa trees. Some of the farmers indicated that they received their fertilizer and pesticide supplies from Ghana Cocoa Board late in the previous year of this study.

Majority of the smallholder farmers interviewed were old and ageing (63.8\% were aged $40-59$ years) with only $10.4 \%$ of the farmers between the ages of $20-39$ years. This has implication on cocoa productivity and production in the future as ones' health normally declines with age. There is the likelihood of decline in the production of cocoa in the study area if the current trend does not change. The finding of farmers aging in this study epitomise what the government calls the "generation gap" threatening future production in the world's second-largest cocoa producing country. The labour-intensive nature of farming could be the reason why youth are not interested in it and will rather migrate to the big cities in search for non-existing jobs. The apparent disinterest in farming by the country's youth is very much a structural issue that has implication for Ghana's future cocoa production.

Low yields in cocoa production as a result of these risks is a threat to the livelihood of smallholder farmers, thereby worsening unemployment and poverty as well as the foreign income earnings of the country. Most of these farmers rely on the income from the sale of cocoa to pay their children's school fees, medical bills and living expenses in general. Crop failure results in children dropping out of school and poor health and nutrition of the family as a whole. The need for farmers to guard against risk of crop failure through farm insurance scheme is therefore crucial.

\section{Type of insurance schemes used by cocoa farmers}

The study revealed that cocoa farmers have never insured their farms before. In spite of this, some farmers were aware and have used a type of insurance before. Out of the 240 farmers sampled, $80 \%$ have already used a type of insurance scheme whiles $20 \%$ have never used insurance schemes before. Majority of the cocoa farmers (61\%) are using the National Health Insurance Scheme (NHIS), followed by auto insurance (8\%) and life policies $(7 \%)$. The reasons farmers gave for using the type of insurance scheme were; to subsidize their medical expenses in times of sicknesses, risk management tool, protection of their properties including family members and protection of their vehicles against future uncertainties (Figs. 1, 2).

\section{Cocoa farmers' knowledge and source of information on crop insurance schemes}

Table 3 presents summary of cocoa farmers' knowledge and sources of information on crop insurance. From the Table, $40 \%$ of the farmers were aware or had knowledge of 


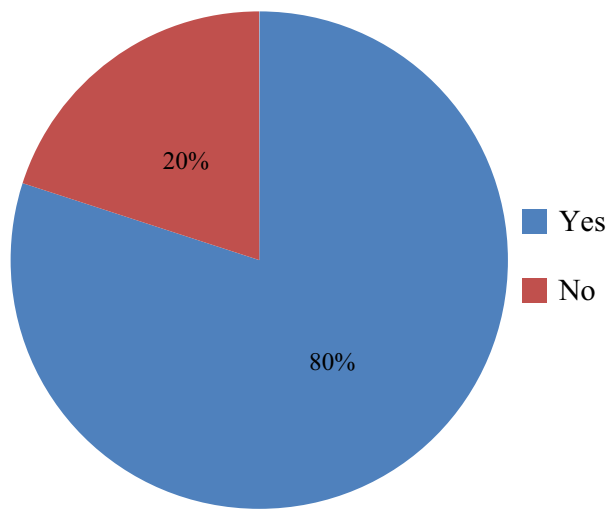

Fig. 1 Percentage of cocoa farmers who use insurance scheme in the study area

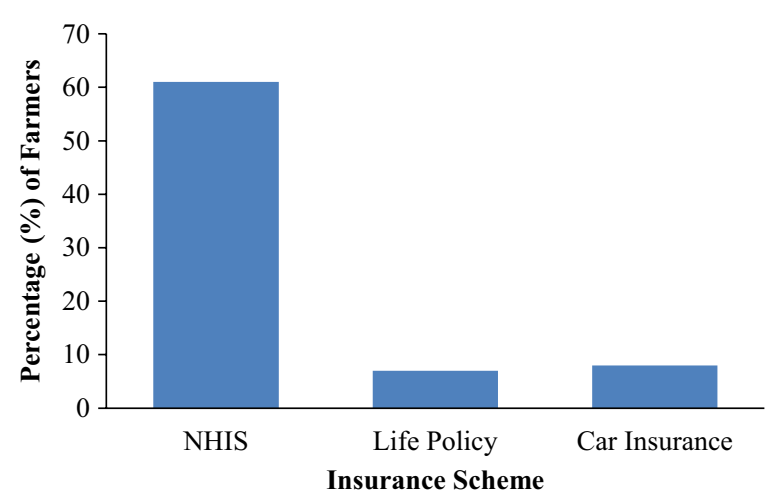

Fig. 2 Type of insurance schemes used by cocoa farmers

Table 3 Cocoa farmer's knowledge and sources of information on crop insurance

\begin{tabular}{|c|c|c|}
\hline & Frequency & Percentage \\
\hline \multicolumn{3}{|l|}{ Knowledge of crop insurance scheme } \\
\hline Yes & 96 & 40.0 \\
\hline No & 144 & 60.0 \\
\hline \multicolumn{3}{|c|}{ Sources of information on crop insurance scheme } \\
\hline Media & 60 & 25 \\
\hline Agricultural extension agents (AEA) & 24 & 10 \\
\hline Farm Based Organization (FBO) & 12 & 5 \\
\hline
\end{tabular}

crop insurance scheme whiles $60 \%$ had no knowledge of crop insurance scheme. Thirty percent (30\%) out of the $40 \%$ who had knowledge of crop insurance schemes indicated that it served as a form of compensation during uncertainties whiles the rest $(10 \%)$ indicated that crop insurance scheme was a type of support from government. The cocoa farmers had information on crop insurance schemes through radio (25\%), Agricultural extension agents (AEA) (10 \%) and Farm Based Organization (FBO) (5\%). 


\section{Farmers' willingness to insure and pay a premium for crop insurance}

Cocoa farmers' willingness to insure and willingness to pay an amount for crop insurance per annum are presented in Table 4 . From the table, majority $(85.4 \%)$ of the cocoa farmers were willing to insure their cocoa farms whiles $14.6 \%$ were not willing to insure their cocoa farms. This indicates farmers' awareness of the importance of crop insurance. The farmers indicated that the crop insurance could guard against loss of crops through theft and perils (fire outbreak, flood and drought). The maximum amount cocoa farmers were willing to pay as premium per acre per annum in order to insure their cocoa farms was GH\$128.40, the minimum amount was $\mathrm{GH} \$ 32.10$ and the average amount was GH\$49.32. Majority (67.80 \%) of the cocoa farmers were willing to pay $10 \%$ of their total production cost (i.e. GH\$ 321.0 on the average) per acre as insurance premium while only $6.83 \%$ were willing to pay $40 \%$ of their production cost as premium. The farmers who were not willing to pay a premium to insure their cocoa farms indicated lack of information or knowledge on crop insurance scheme.

Factors influencing farmers' willingness to insure and willingness to pay for crop insurance The factors influencing farmers' willingness to insure and willingness to pay amount for crop insurance are presented in Table 5. From the Table, gender has no significant influence on both willingness to insure and willingness to pay for crop insurance. This result is consistent with the findings of Curak et al. (2013) who assert that gender has no significant relationship with insurance policy. Even though it was not significant, it did not conform to the a-prior expectation which is positive. This may be as a result of the fact that even though male farmers are well endowed, they are risk loving compared to female farmers, hence, may not see the need to insure their farms and pay for insurance premium. Studies have shown that women are more risk averse than men (Palsson 1996; Donkers et al. 2001; Hartog et al. 2002; Cohen and Einav 2007; Dohem et al. 2011). This means that men are risk loving and would be less likely to take risk reduction strategies such as insurance even though they are endowed than women.

However, the age of farmers was statistically significant at $5 \%$ and positively influenced willingness to insure crops. This however did not conform to the a prior expectation. The result revealed that as a farmer's age increases, he/she is more likely to insure his/her cocoa farm. The result however contradicted findings by Baidu-Forson (1999), Langyintuo and Mulugetta (2005) and Aidoo et al. (2014) which stated that older farmers

Table 4 Cocoa farmers' willingness to insure and the amount to pay for crop insurance

\begin{tabular}{lll}
\hline Variable & Description & Percentage (\%) \\
\hline Willing to insure cocoa farms & Yes & 85.4 \\
Percentage of total production cost/acre/annum farmers & No & 14.6 \\
are willing to pay as premium & 10 & 67.80 \\
& 20 & 17.56 \\
Minimum premium willing to pay/acre/annum & 30 & 7.80 \\
Maximum premium willing to pay/acre/annum & 40 & 6.83 \\
Average amount farmers are willing to pay per acre per annum & GHC32.10 & 67.80 \\
\hline
\end{tabular}


Table 5 Double Hurdle Model on factors influencing farmers' willingness to insure and pay for crop insurance

\begin{tabular}{|c|c|c|c|c|c|c|c|}
\hline \multicolumn{5}{|c|}{ Willingness to insure } & \multicolumn{3}{|c|}{ Willingness to pay } \\
\hline \multicolumn{5}{|l|}{ Probit } & \multicolumn{3}{|l|}{ Tobit } \\
\hline Variables & $d y / d x$ & Coeff. & Std. Error & $p>z$ & Coeff. & Std. Error & $p>z$ \\
\hline Gender & -0.00668 & -0.14677 & 0.40268 & 0.716 & -4.05602 & 3.19595 & 0.206 \\
\hline Age & 0.002997 & 0.06020 & 0.02545 & $0.018^{* *}$ & 1.42499 & 0.141128 & $0.000^{* * *}$ \\
\hline Mstatus & 0.23526 & 1.86291 & 0.38959 & $0.000^{* * *}$ & -27.7962 & 3.00312 & $0.000^{* * *}$ \\
\hline Hsesize & -0.01774 & -0.35628 & 0.10474 & $0.001^{* * *}$ & 2.46747 & 0.68126 & $0.000^{* * *}$ \\
\hline Educ & 0.03674 & 2.11833 & 0.72420 & $0.003^{* * *}$ & -2.98324 & 4.13594 & 0.472 \\
\hline Croparea & -0.00277 & -0.05572 & 0.01881 & $0.003^{* * *}$ & 0.56288 & 0.16897 & $0.001^{* * *}$ \\
\hline Cocoainc & 0.01446 & 0.29049 & 0.61013 & 0.634 & -8.53390 & 4.84956 & $0.080^{*}$ \\
\hline Otherinc & -0.00244 & -0.04898 & 0.36340 & 0.893 & -0.00444 & 2.41869 & 0.999 \\
\hline Constant & - & -2.78862 & 6.47976 & 0.667 & 54.48673 & 48.37018 & 0.261 \\
\hline \multicolumn{2}{|c|}{ Regression diagnostics } & \multicolumn{2}{|c|}{ Value } & \multicolumn{3}{|c|}{ Regression diagnostics } & Value \\
\hline \multicolumn{2}{|c|}{ Number of observations } & \multicolumn{2}{|c|}{240} & \multicolumn{3}{|c|}{ Cragg \& Uhler's $R^{2}$} & 0.690 \\
\hline \multicolumn{2}{|c|}{ Log-likelihood } & \multicolumn{2}{|c|}{-40.4804} & \multicolumn{3}{|c|}{ Efron's $R^{2}$} & 0.545 \\
\hline \multicolumn{2}{|l|}{$\operatorname{LR} x^{2}(8)$} & \multicolumn{2}{|c|}{118.437} & \multicolumn{3}{|c|}{ McKelvey and Zavoina's $R^{2}$} & 0.704 \\
\hline \multicolumn{2}{|l|}{ Prob $>x^{2}$} & \multicolumn{2}{|c|}{0.000} & \multicolumn{3}{|c|}{ Count $R^{2}$} & 0.917 \\
\hline \multicolumn{2}{|l|}{ Pseudo $R^{2}$} & \multicolumn{2}{|c|}{0.5940} & \multicolumn{3}{|l|}{ AlC } & 0.412 \\
\hline \multicolumn{2}{|c|}{ Maximum likelihood $\mathrm{R}^{2}$} & \multicolumn{2}{|c|}{0.390} & \multicolumn{3}{|c|}{ Variance of $\mathrm{y}^{*}$} & 3.375 \\
\hline \multicolumn{2}{|c|}{ McFadden's $R^{2}$} & \multicolumn{2}{|c|}{0.594} & \multicolumn{3}{|c|}{ Variance of error } & 1.00 \\
\hline
\end{tabular}

***,**, and $* 1,5$ and $10 \%$ significant levels respectively

are less likely to insure their farms. Again, age positively influenced the amount a cocoa farmer is willing to pay for crop insurance and was statistically significant at $1 \%$. This shows that as the age of a cocoa farmer increases by 1 year, the amount he/she is willing to pay increases by GHष1.42.

Similarly, marital status was statistically significant at $1 \%$ and positively influenced farmers' willingness to insure their cocoa farms. The result again revealed that the likelihood of a married farmer insuring his/her farm is 0.235 . However, marital status negatively influenced the amount (premium) cocoa farmers are willing to pay for crop insurance and this was statistically significant at $1 \%$. Thus, the amount (premium) a farmer was willing to pay if married decreases by GH\$27.80.

Household size was statistically significant at $1 \%$ and negatively influenced a farmer's willingness to insure his/her cocoa farm. This means that as the household size of a cocoa farmer increases by one person, the likelihood of him/her insuring his/her farm reduce by 0.018 . This result is in line with findings of Falola et al. (2013) and DansoAbbeam et al. (2014). However, the amount a farmer is willing to pay increases by GH\$2.47 as his/her household size increase by one person.

The educational level of cocoa farmers positively influenced their willingness to insure their cocoa farms and was significant at $1 \%$. Thus, the higher the educational level of a farmer, the more likely he/she would be willing to insure his/her cocoa farm. This conformed to the a prior expectation and is in line with findings of Piyasiri and Ariyawardana (2002), Falola et al. (2013), Aidoo et al. (2014) and Danso-Abbeam et al. (2014). The results could be explained by the fact that a farmer who gains formal education can 
critically analyze and make own decisions between technologies as revealed by Enete and Igbokwe (2009) and Caleb and Ramatu (2013). However, education did not significantly influence the premium a cocoa farmer was willing to pay for crop insurance.

Size of cropped area was statistically significant at $1 \%$ and negatively influenced a farmer's willingness to insure his/her cocoa farm. Thus, the bigger the cropped area the less likely a farmer would be willing to insure his/her farm. From the results, as the size of cropped area increases by one acre, the probability that a cocoa farmer would insure his farm reduces by 0.003 . The results again revealed that the amount (premium) farmers are willing to pay for crop insurance is positively influenced by size of cropped area and statistically significant at $1 \%$. This means that as size of cropped area increases by one acre, the amount (premium) farmers are willing to pay for crop insurance increases by GH 0.56 . This contradicts the findings of Kumar et al. (2011) which reported that size of cropped area negatively influence willingness to pay an amount for crop insurance.

Income from cocoa did not significantly influence a farmer's willingness to insure his/ her cocoa farm. However, it had a positive effect and conforms to the a-prior expectation. This findings contradicts the findings of Danso-Abbeam et al. (2014) who reported that cocoa income significantly and positively influence a farmer's willingness to insure his/her cocoa farm. However, cocoa income was statistically significant at $10 \%$ and negatively influenced the premium cocoa farmers are willing to pay for crop insurance. Thus, if a cocoa farmer's income increases by GH\$1.00, the amount he/she would be willing to pay decreases by $\mathrm{GH} \$ 8.53$.

Income from other sources was not significant and negatively influenced both farmer's willingness to insure his/her cocoa farm and the amount a cocoa farmer would be willing to pay for crop insurance. This could be explained by the fact that as a farmer diversifies his income sources, he/she feels secured, therefore, would not be willing to insure and pay for crop insurance.

\section{Insurance companies' willingness to provide crop insurance scheme to cocoa farmers}

The insurance companies interviewed provide insurance schemes other than agricultural insurance scheme. The insurance policies offered by these companies were auto insurance (comprehensive and third party auto insurance), fire and related risks (loss of property through fire, explosion, and lighting), burglary (loss of property through theft) and life (injuries and death).

It was noted that all the insurance companies did not have crop insurance scheme as part of their operations. However, $80 \%$ of the insurance companies were aware of crop insurance schemes. Reasons were sort as to why they had no crop insurance policy. These companies indicated that the high risk of the agricultural sector was the main reason for not offering insurance policy as the sector in Ghana is highly dependent on rainfall with most farmers using low input or no input in their farm. For most of these companies, the smallholder farmers who form the larger portion of farmers may not be able to afford the crop insurance. Some companies however indicated there is a proposal to undertake crop insurance and it is awaiting approval.

Although the insurance companies did not have crop insurance as part of their insurance policies, $40 \%$ of the companies were willing to carry out crop insurance for cocoa farmers if proposal is approved. The insurance companies indicated that they are willing 
Table 6 Awareness of insurance companies on farm insurance policies and interest in providing farm insurance policies or schemes to farmers

\begin{tabular}{lll}
\hline Variable & Description & Percentage (\%) \\
\hline Awareness on crop insurance & Yes & 80 \\
Interest in crop insurance polices & No & 20 \\
& Yes & 40 \\
& No & 60 \\
\hline
\end{tabular}

to provide crop insurance for cocoa farms because cocoa is an export commodity and therefore, generate enough income for farmers. In addition, they indicated that cocoa is a tree crop and therefore, farmers cannot easily switch to different crop once they log on to the crop insurance policy (Unlike annual crops where a farmer can decide not to grow that same crop the following year which can distort continues flow of payment and record). The $60 \%$ of the companies who were reluctant to undertake crop insurance gave the following reasons; agriculture is highly risky, lack of income diversification activities among the farmers, agricultural produce are highly perishable and lastly, farmers do not use modern ways of cultivation (lack of adoption of technology among farmers).

Even though the insurance companies were willing to provide crop insurance to cocoa farmers, the insurance companies indicated the need for awareness creation and education of farmers on the need to adopt crop insurance schemes, adopt modern ways of cultivation and good record keeping (Table 6).

\section{Conclusions and recommendations}

The study shows that majority ( $80 \%$ ) of cocoa farmers have used National Health Insurance Scheme (NHIS), life policy and auto insurance but have never used crop insurance. This is due to lack of crop insurance scheme. However, $40 \%$ of the farmers are aware or have knowledge of crop insurance from the media, AEAs and FBOs. This shows that crop insurance is not popular among cocoa farmers.

Majority of the cocoa farmers $(85.40 \%)$ were willing to insure their cocoa farms. However, only $6.83 \%$ of the farmers are willing to pay the maximum premium of GH\$128.40. It could be deduced that though the farmers were willing to insure their farms, their willingness to insure did not mean majority would pay higher premium.

In assessing factors influencing farmers' willingness to insure and willingness to pay for crop insurance, the double-hurdle model was used. Age, marital status and education significantly and positively influenced cocoa farmers' willingness to insure their farms whiles household size and cropped area significantly and negatively influenced cocoa farmer's willingness to insure their farms. Similarly, age, household size and cropped area significantly and positively influenced the premium cocoa farmers were willing to pay whiles marital status and cocoa income significantly and negatively influenced the premium cocoa farmers were willing to pay.

Insurance companies did not have crop insurance scheme as part of their operations although majority were aware of crop insurance scheme. However, the insurance companies were willing to provide crop insurance to cocoa farmers if only farmers adopt 
modern ways of cultivation to reduce the risk involved in production and also have good record keeping.

It is recommended that cocoa farmers be well informed and educated on crop insurance and the need to insure their cocoa farms since majority were not aware or had no knowledge of crop insurance. This could also increase the premium they will be willing to pay for crop insurance. Farmers should be involved in planning the crop insurance scheme in order to conclude on the premium to be paid by the cocoa farmers. There is a need for further research to determine the premium farmers are willing to pay and the factors which influence the premium farmers are willing to pay.

\section{Abbreviations}

GH: Ghana; WTP: willingness to pay; WTI: willingness to insure; GDP: gross domestic product; NHIS: National Health Insurance Scheme; AEA: agricultural extension agents; FBO: farm based organization; COCOBOD: Ghana Cocoa Board.

\section{Authors' contributions}

FMBY and EDO designed the study and developed the questionnaire, EDO collected data, EKD and DTA analyzed the data, FMBY, EDO, and EKD drafted the manuscript, FMBY and DTA reviewed and edited the manuscript. All authors read and approved the final manuscript.

\section{Author details}

${ }^{1}$ Institute for Environment and Sanitation Studies (IESS), University of Ghana, P. O. Box 209, Legon, Accra, Ghana. ${ }^{2}$ Department of Agricultural Economics and Agribusiness, University of Ghana, P. O. Box LG 68, Legon, Accra, Ghana.

\section{Acknowledgements}

We wish to thank all farmers in Dormaa West for participating in the survey. We also wish to thank the insurance companies for their contribution to this research.

\section{Competing interests}

The authors declare that they have no competing interests.

Received: 29 January 2016 Accepted: 10 June 2016

Published online: 24 June 2016

\section{References}

Adams (1995) Banking and finance series investment. Kluwer Law International, London

Aidoo R, Mensah Osei J, Wie P, Awunyo-Vitor D (2014) Prospects of crop insurance as a risk management tool among arable crop farmers in Ghana. Asian Econ Financ Rev 4(3):341-354

Anang BT (2011) Market structure and competition in the Ghanaian cocoa sector after partial liberalization. Curr Res $J$ Soc Sci 3(6):465-470

Aneani F, Anchirinah VM, Owusu-Ansah F, Asamoah M (2012) Adoption of some cocoa production technologies by cocoa farmers in Ghana. Sustain Agric Res 1(1):103-117. doi:10.5539/sar.v1n1p103

Anim-Kwapong GJ, Frimpong EB (2004) Vulnerability and adaptation assessment under the Netherlands climate change studies assistance programme phase 2 (NCCSAP2): vulnerability of agriculture to climate change-impact of climate on cocoa production. Cocoa Research Institute of Ghana, Ghana

Antwi-Agyakwa AK (2013) Susceptibility of field populations of cocoa mirids, sahlbergella singularis haglund and distantiella theobroma (distant) to bifenthrin. (A Published Master's thesis), Kwame Nkrumah University of Science and Technology, Kumasi, Ghana. Retrieved from http://hdl.handle.net/123456789/6471

Appiah MR (2004) Impact of cocoa research innovations on poverty alleviation in Ghana. Ghana Acad Arts Sci Publ Asamoah M, Baah F (2003) Improving Research-Farmer linkages: The role of CRIG. In: A paper submitted at the 4th international seminar on cocoa Pests and Diseases (NECOPED). Accra, Ghana. 19th-21st October 2003

Ayenor GK, Huis AV, Obeng-Ofori D, Padi B, Röling NG (2007) Facilitating the use of alternative capsid control methods towards sustainable production of organic cocoa in Ghana. Int J Trop Insect Sci 27(02):85-94. doi:10.1017/ S1742758407780840

Ayisu S (2008) An analysis of factors influencing credit default, a case study of maize farmers in Agogo. (Unpublished Masters Thesis), Department of Agricultural Economics, Agribusiness and Extension, Faculty of Agriculture, Kwame Nkrumah University of Science and Technology, Kumasi, Ghana

Baidu-Forson J (1999) Factors influencing adoption of land-enhancing technology in the sahel: lessons from a case study in Niger. J Agric Econ 20(3):231-239

Bailey AB, Mary DS, Hanhong BG, Antunez De Ayolo G, Guiltinan MJ (2005) Gene expression in leaves of theobroma cacao in response to mechanical wounding, ethylene, and/or methyl jasmonate. Plant Sci 168:1247-1258

Caleb D, Ramatu A (2013) factors influencing participation in rice development projects: the case of smallholder rice farmers in Northern Ghana. Int J Dev Econ Sustain 1(2):13-27

Cohen A, Einav L (2007) Estimating risk preferences from deductible choice. Am Econ Rev 97(3):745-788 
Cragg JG (1971) Some statistical models for limited dependent variables with application to the demand for durable goods. Econometrica 39:829-844

Curak M, Džaja I, Pepur S (2013) The effects of social and demographic factors on life insurance demand in Croatia. Int J Bus Soc Sci 4(9):65-72

Danso-Abbeam G, Setsoafia ED, Gershon I, Ansah K (2014) Modelling farmers investment in agrochemicals: the experience of smallholder cocoa farmers in Ghana. Res Appl Econ 6(4):1-15. doi:10.5296/rae.v6i4.5977

Dohem T, Falk D, Huffman D, Sunde U, Schupp J, Wagner GG (2011) Individual risk attitudes: measurement, determinants and behavioral consequences. J Eur Econ Assoc 9(3):522-550

Donkers B, Melenberg B, Van Soest A (2001) Estimating risk attitudes using lotteries: a large sample approach. J Risk Uncertain 22(2):165-195

Dormon ENA, Van Huis A, Leeuwis C, Obeng-Ofori D, Sakyi-Dawson O (2004) Causes of low productivity of cocoa in Ghana: farmers' perspectives and insights from research and the socio-political establishment. NJAS Wageningen J Life Sci 52(3-4):237-259. doi:10.1016/S1573-5214(04)80016-2

Dormon ENA, Huis AV, Leeuwis C (2007) Effectiveness and profitability of pest management for improving yield on small holder cocoa farms in Ghana. Int J Trop Insect Sci 27(1):27-39. doi:10.1017/S1742758407727418

Duguma B, Gockowski J, Bakala J (1998) Smallholder cocoa (Theobroma cacao) cultivation in agroforestry systems of west and central Africa. Challenges and opportunities. In 1st sustainable Cocoa Congress

Enete AA, Igbokwe EM (2009) Cassava market participation decisions of producing households in Africa. Tropicultura 27(3):129-136

Falola A, Ayinde OE, Agboola BO (2013) Willingness to take agricultural insurance by cocoa farmers in Nigeria. Int J Food Agric Econ 1(1):97-107

Freshwater D, Jette-Nantel S (2008) Agricultural risk management through household portfolio choice. Paper developed for the 2008 NAREA Agricultural Policy workshop, June 2008

Gabre-Madhin E, Barret CB, Dorosh P (2003) Technological change and price effects in agriculture: Conceptual and comparative perspectives. (No. MTID Discussion Paper No. 62, IFPRI).Washington, DC, USA

Ghana Statistical Service (2014) 2010 Population and Housing Census: District Analytical Report of Dormaa West

Gockowski J, Afari-Sefa V, Sarpong DB, Osei-Asare YB, Dziwornu AK (2011) Increasing income of ghanaian cocoa farmers: is introduction of fine flavour cocoa a viable alternative. Q J Int Agric 50(2):175-200

Hartog J, Ferrer-i-Carbonell A, Jonker N (2002) Linking measured of risk aversion to individual characteristics. Kyklos 55(1):3-26

Institute of Statistical Social and Economic Research (ISSER) (2010) The State of the Ghanaian Economy 2009. Institute of Institute of Statistical Social and Economic Research, University of Ghana, Legon

Institute of Statistical Social and Economic Research (ISSER) (2014) The State of the Ghanaian Economy in 2013. University of Ghana, Legon

International Cocoa Organisation (ICCO) (2015) Pest and disease related damages to cocoa crops. Icco.org. Retrieved 17 March 2016, from http://www.icco.org/about-cocoa/pest-a-diseases.html

IPCC (2014) Climate change 2014: Impacts, adaptation, and vulnerability. Working group II contribution to the fifth assessment report of the Intergovernmental Panel on Climate Change. Technical Report. Cambridge University Press, Cambridge, UK/New York, USA

Jonny GMV, Barbara JR, Julie F (2003) Discovery learning about cocoa: an inspirational guide for training facilitators. Cabi Bioscience, U.K Centre, Oxon

Kimengsi JN, Tosam JN (2013) Climate variability and cocoa production in meme division of cameroon: agricultural development policy options by policy options. Greener J Agric Sci 3(8):606-617

Kumar D, Barah BC, Ranganathan CR, Venkatram R, Gurunathan S, Thirumoorthy S (2011) An analysis of farmers' perception and awareness towards crop insurance as a tool for risk management in Tamil Nadu. Agric Econ Res Rev 24:37-46

Kwadzo GT, Kuwornu JKM, Amadu ISB (2013) Food crop farmers' willingness to participate in market-based crop insurance scheme: evidence from Ghana. Res Appl Econ 5(1):1-21. doi:10.5296/rae.v5i1.2617

Lanaud C, Fouet O, Clément D, Boccara M, Risterucci AM, Surujdeo-Maharaj S, Legavre T, Argout X (2009) A metaQTL analysis of disease resistance traits of Theobroma cacao L. Mol Breeding 24(4):361-374. doi:10.1007/ s11032-009-9297-4

Langyintuo AS, Mulugetta M (2005) Modeling agricultural technology adoption using the software STATA. International Maize and Wheat Improvement Center (CIMMYT) Training Manual No. 1/2005 (Part two)

Lass T (2004) Balancing cocoa production and consumption. In Flood J, Murphy R (Eds.), In Cocoa futures. A source book of some important issues confronting the cocoa industry. Colombia/CAB International, UK.: The Commodities Press, Cenicafe

Laux P, Jäckel G, Tingem RM, Kunstmann H (2010) Impact of climate change on agricultural productivity under rain fed conditions in Cameroon-A method to improve attainable crop yields by planting date

Liu Z, Zhang W (2011) Which factors affect farmers' willingness for soil testing technology adoption: a case study of Tai Lake Watershed, China

Longe OA, Oyekale AS (2013) Assessment of climate change vulnerability and adaptation among smallholder cocoa farmers in Osun State, Nigeria. Life Sci J 10(2):757-763

Lubungu M, Chapoto A, Tembo G (2012) Smallholder farmers participation in livestock markets: The case of Zambian farmers. (No. Working Paper, 66)

Mahrizal Nalley LL, Dixon BL, Popp JS (2014) An optimal phased replanting approach for cocoa trees with application to Ghana. Agric Econ (United Kingdom) 45(3):291-302. doi:10.1111/agec.12065

McConnell CR, Brue SL, Flynn SM (2009) Economics: principles, problems, and policies, 18th edn. McGraw-Hill Series, New York

Musah AB (2013) Market participation of smallholder farmers in the Upper West Region of Ghana. (Unpublished Thesis). Department of Agricultural economics and Agribusiness, University of Ghana 
Nakanyike S (2014) Farmers' willingness to pay for virus-free sweet potato vines in Central Uganda: a case of Mpigi and Wakiso Districts. (Unpublished Masters Thesis). Makarere University, Uganda

Nimo F, Baah K, Tham-Agyekum EK (2011) Investigating the interest of farmers and insurance companies in farm insurance: the case of cocoa farmers in Sekyere West municipal of Ghana. J Agric Sci 3(4):126-135

Norris PE, Batie SS (1987) Virginia farmers' soil conservation decisions: an application of the tobit analysis. South J Agric Econ 19:79-90

Ntiamoah A, Afrane G (2008) Environmental impacts of cocoa production and processing in Ghana: life cycle assessment approach. J Clean Prod 16:1735-1740. doi:10.1016/j.jclepro.2007.11.004

Palsson A (1996) Does the degree of relative risk aversion vary with household characteristics? J Econ Psychol 17:771-787

Piyasiri AGSA, Ariyawardana A (2002) Market potentials and willingness to pay for selected organic vegetables in Kandy, Sri Lankan. J Agric Econ 4:107-119

Quagrainie K (2006) IQF catfish retail pack: a study of consumers' willingness to pay. Int Food Agribus Man Rev 9(2):75-87

Sadoulet E, Janvry DA, Benjamin C (1996) Household behaviour with imperfect labor markets. California Agricultural Experiment Station, GIANNINI Foundation of Agricultural Economics

Sarris A, Karfakis P, Christiaensen L (2006) "Producer demand and welfare benefits of minimum price insurance for export crops in Tanzania." FAO commodity and trade policy research working paper. (No. 18)

Sindi JK (2008) Kenya's domestic horticulture subsector: what drives commercialization decisions by rural households? (A Published MSc. Thesis), Department of Agricultural, Food, and Resource Economics, Michigan State University

Swiss R (2007) Insurance in emerging markets: sound development; Greenfield for agricultural insurance. Swiss Reinsurance Company, Zurich

Taneja G, Pal BD, Joshi PK, Aggarwal PK, Tyagi NK(2014) Farmers' preferences for climate-smart agriculture an assessment in the Indo-Gangetic Plain (No. IFPRI Discussion Paper 01337)

Ulimwengu J, Sanyal P (2011) Joint estimation of farmers'stated willin gness to pay for agricultural services. IFPRI Discussion Paper 01070

Vandeveer ML, Loehman ET (1994) Farmer response to modified crop insurance: a case study of corn in Indiana. Am J Agric Econ 76:128-140

Wodjao TB (2008) A double-hurdle model of computer and internet use in American households. Department of Economics, Western Michigan University, Michigan

Yu X, Abler D (2010) Incorporating zero and missing responses into CVM with open-ended bidding: willingness to pay for Blue Skies in Beijing. Environ Dev Econ 15:535-556. doi:10.1017/S1355770X10000197

\section{Submit your manuscript to a SpringerOpen ${ }^{\circ}$ journal and benefit from:}

- Convenient online submission

\section{- Rigorous peer review}

- Immediate publication on acceptance

Open access: articles freely available online

- High visibility within the field

Retaining the copyright to your article

Submit your next manuscript at $>$ springeropen.com 